Effects of ABRC module utilization in improving the reading comprehension of grade 5 pupils in Tangway Loob elementary school

De Belen, Angelina M.

Tangway Loob Elementary School, Philippines (angelina.debelen14@gmail.com)

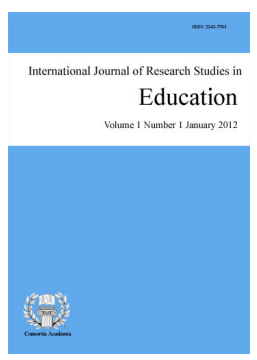

ISSN: $2243-7703$ Online ISSN: 2243-7711

OPEN ACCESS

\title{
Abstract
}

Reading comprehension is an essential skill for learners of English. For most of learners it is the most important skill to master in order to ensure success in learning. With strengthened reading skills, learners of English tend to make greater progress in other areas of learning. Reading should be an active, fluent process that involves the reader and the reading material in building meaning. Thus, the researcher uses the ABRC Module to increase the reading comprehension of Grade 5. This study aimed to improve the reading comprehension of Grade 5 through the use of ABRC Module. This includes thirty seven pupils. The descriptive method of research was used in this study with the Phil-IRI pre and post test results as the primary data gathering tools. There will be one group: the experimental. The data to be gathered will be statistically treated with the use of weighted mean and standard deviation. The results will be analyzed and tabulated through tables. The results revealed that $100 \%$ of the pupils increased their level comprehension after using the ABRC Module.

Keywords: ABRC module; experimental study; elementary students; Philippines 


\section{Effects of ABRC module utilization in improving the reading comprehension of grade 5 pupils in Tangway Loob elementary school}

\section{Introduction}

Reading comprehension over the last 25 years have made great strides in learning how to teach children to read words, but there has been considerably less progress in tackling the challenge of helping students understand the words they need. In the past years, however, improving students' reading comprehension has become a research priority. There are many challenges that confront educators and practitioners faced with helping struggling readers improve their understanding of texts.

Poor comprehension struggle with issues related to inadequate background, language knowledge, and engagement. Improving comprehension abilities thus is not simply a matter of teaching students some strategies to use while reading, rather, it involves providing students with the different activities like ABRC Modules which consists different skills like noting details, getting the main idea, predicting outcomes, sequencing and cause and effect. This is a modular approach to develop the critical thinking of the students. It is made up of six (6) levels contained in boxes. There are thirty five (35) exercises per skill followed by questions to test the comprehension of each pupil. Hopefully, this module will help Grade 5 pupils in improving their reading comprehension.

The researcher will conduct this study for the purpose of improving the grade 5 pupils in reading comprehension, especially in noting details, getting the main idea, predicting outcomes, sequencing and cause and effect using the ABRC Module.

\subsection{Statement of the problem}

This study aims to improve the reading comprehension of Grade 5 pupils in Tangway Loob Elementary School using the ABRC module. Specifically, would like to answer the following:

$>\quad$ What is the comprehension level of Grade 5 pupils before the utilization of the ABRC module?

$>$ What is the pupils' comprehension level in each reading subskills which were included in the ABRC module? Such as: Noting details, getting the main idea, predicting outcome, sequencing, and cause and effect.

$>\quad$ What is the comprehension level of Grade 5 pupils after the use of ABRC module?

$>\quad$ Is there a significance difference in the comprehension of the pupils before and after the utilization of the ABRC module?

$>\quad$ What plan of action can be proposed to further improve the performance in reading of Grade 5 pupils?

\section{Brief review of related literature}

Reading comprehension is one of the pillars of the act of reading. When a person reads a text he engages on a complex array of cognitive processes. He is simultaneously using his awareness and understanding of phonemes. These are actually the individual sound pieces in language, phonics (connection between letters and sounds and the relationship between sounds, letters and words), and the ability to comprehend or construct meaning from the text. This last component of the act of reading is reading comprehension. It cannot function independent of the other two elements of the process. At the same time, it is the most difficult and most important of the three. 
Historically teachers and researchers have believed that the ability to comprehend text is 'caught rather than taught.' If reading meant catching a meaning known only to the author, teaching reading had to mean finding out whether or not students got it. Instruction in America's elementary reading classes has been based on this theory; a series of comprehension questions - coming from the basal reader or the teacher - were posed, and the goal was to see if children could answer them (caught them) in the way the teacher believed they should. Many teachers taught what the previous practitioners told them to teach: skills such as homonyms, suffixes, main ideas, as well as scores of other fragments of reading. Reading classes were typically structured and predictable: three reading groups a day and plenty of seat work time to complete skill sheets. Rarely were students taught how to comprehend and analyze full sections of text (Keene \& Zimmermann, 1997).

According to Armbuster, Lehr, and Osborn (2001) monitoring teaches students to be aware of what they do understand, identify what they do not understand, and use appropriate "fix-up" strategies to resolve problems in comprehension. Reciprocal teaching is a teaching process developed by Palinscar and Brown (1985) to help students develop the metacognitive strategies needed to construct meaning from text. The goals of reciprocal teaching include improving student comprehension and the students 'ability to self-monitor their comprehension while reading. In his constructivist approach, students are trained to utilize four strategies while reading: generating questions, summarizing, clarifying, and predicting. Reciprocal teaching can be employed several ways: one-to-one, small group teacher facilitated, whole group teacher facilitated, and small group peer facilitated (Palinscar \& Brown, 1985).

\subsection{Theoretical framework}

This research work was based on the Schema Theory which states that readers can better understand what they are reading when they have general background knowledge of the topic being presented. This existing information is used by the reader to tie together the individual sentences and paragraphs in a passage.

Previewing helps readers activate their background knowledge and form a schema or outline about the topic. As the reader previews a passage, he or she calls to mind previous experience or mental associations; in other words the reader gets the mind ready to take in new information about the topic. This "mental readiness" helps the reader fill in missing information and connect sentences and paragraphs.

\subsection{Conceptual framework}

The conceptual framework of the study provides the basis on how the researcher goes through with the various processes involved.

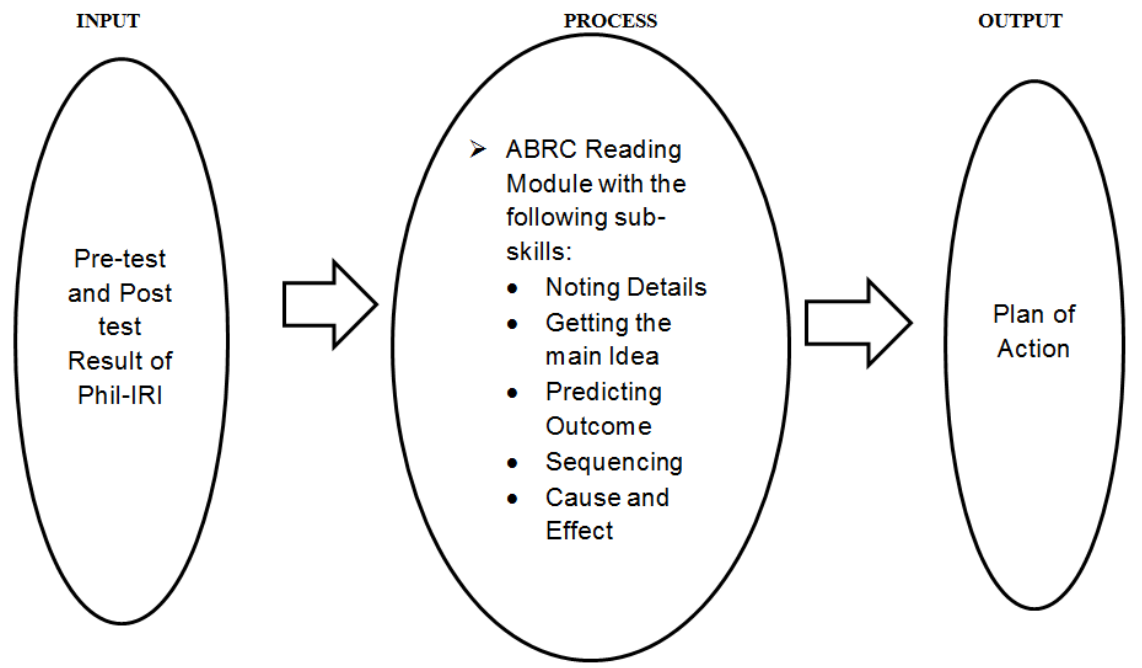

Figure 1. Conceptual paradigm 
De Belen, A. M.

This study was anchored on the pre-test and post-test of Phil-IRI in improving the reading comprehension with the different sub-skills, noting details, getting the main idea, predicting outcomes, sequencing and giving cause and effect.

\subsection{Research design and methodology}

The research will adopt a descriptive research design. This study will use the pre-test and post-test of Phil-IRI to gather data. The data to be gathered will be analyzed using percentage and standard deviation. Results will be analyzed and tabulated through tables.

\section{Results and discussion}

From the data gathered, analyzed and interpreted, the following findings were summarized. Note the names of the students are deliberately truncated to protect their actual identity.

\section{Table 1}

Pre-test results of the Phil-IRI

\begin{tabular}{|c|c|c|c|c|}
\hline & Name of pupils & Independent & Instructional & Frustration \\
\hline 1. & Apoya & & & $\mathrm{X}$ \\
\hline 2. & Barles & & & $\mathrm{X}$ \\
\hline 3. & Bilog & & & $\mathrm{X}$ \\
\hline 4. & Espinosa & $\mathrm{X}$ & & \\
\hline 5. & Gidoc & & & $X$ \\
\hline 6. & Hernandez & & & $\mathrm{X}$ \\
\hline 7. & Landicho & & & $X$ \\
\hline 8. & Las & & & $\mathrm{X}$ \\
\hline 9. & Leyrit & & & $\mathrm{X}$ \\
\hline 10. & Llanes & & & $\mathrm{X}$ \\
\hline 11. & Marasigan & & & $\mathrm{X}$ \\
\hline 12. & Mendoza & & & $\mathrm{X}$ \\
\hline 13. & Mercado & & & $\mathrm{X}$ \\
\hline 14. & Mosca & & & $\mathrm{X}$ \\
\hline 15. & Orola & & $\mathrm{X}$ & \\
\hline 16. & Palomino, A & & & $\mathrm{X}$ \\
\hline 17. & Palomino, Z & & & $\mathrm{X}$ \\
\hline 18. & Salon & & $\mathrm{X}$ & \\
\hline 19. & Umali & & & $\mathrm{X}$ \\
\hline 20. & Abanilla & & $X$ & \\
\hline 21. & Balat. & & $X$ & \\
\hline 22. & Dalangin & & $\mathrm{X}$ & \\
\hline 23. & Gadingan & $X$ & & \\
\hline 24. & Landicho & & & $X$ \\
\hline 25. & Las & & & $X$ \\
\hline 26. & Leyesa & & & $\mathrm{X}$ \\
\hline 27. & Llanes & & & $\mathrm{X}$ \\
\hline 28. & Mendoza & & & $\mathrm{X}$ \\
\hline 29. & Moster & & & $\mathrm{X}$ \\
\hline 30. & Navarro & & & $\mathrm{X}$ \\
\hline 31. & Pader & $\mathrm{X}$ & & \\
\hline 32. & Palomino, $\mathrm{K}$ & $\mathrm{X}$ & & \\
\hline 33. & Pasahol, E & & $\mathrm{X}$ & \\
\hline 34. & Pasahol, L & & & $\mathrm{X}$ \\
\hline 35. & Claveria & & & $\mathrm{X}$ \\
\hline 36. & Millave & & $X$ & \\
\hline 37. & April & & & $\mathrm{X}$ \\
\hline
\end{tabular}

Table 1 shows the Pretest Result of PHIL-IRI of Grade V pupils. Independent pupils got 4 or $11 \%$ of the total population. Instructional pupils obtained a score of 7 or $19 \%$ of the class. Frustration got the highest number of 26 or $70 \%$.It shows that there is a need of intervention in reading since $70 \%$ of the children fell on the frustration level.

68 Consortia Academia Publishing (A partner of Network of Professional Researchers and Educators) 
Effects of ABRC module utilization in improving reading comprehension of pupils in Tangway Loob school

Table 2

Comprehension level of pupils in each reading sub-skills

\begin{tabular}{|c|c|c|c|c|c|c|c|c|c|c|}
\hline \multirow{2}{*}{$\begin{array}{l}\text { Name of } \\
\text { Pupils }\end{array}$} & \multicolumn{2}{|c|}{ Noting details } & \multicolumn{2}{|c|}{$\begin{array}{l}\text { Getting the } \\
\text { main idea }\end{array}$} & \multicolumn{2}{|c|}{$\begin{array}{l}\text { Predicting } \\
\text { outcome }\end{array}$} & \multicolumn{2}{|c|}{$\begin{array}{c}\text { Sequencing of } \\
\text { events }\end{array}$} & \multicolumn{2}{|c|}{$\begin{array}{c}\text { Cause and } \\
\text { effect }\end{array}$} \\
\hline & $\%$ & $\begin{array}{l}\text { Com. } \\
\text { Level }\end{array}$ & $\%$ & $\begin{array}{l}\text { Com. } \\
\text { Level }\end{array}$ & $\%$ & $\begin{array}{l}\text { Com. } \\
\text { Level }\end{array}$ & $\%$ & $\begin{array}{l}\text { Com. } \\
\text { Level }\end{array}$ & $\%$ & $\begin{array}{l}\text { Com. } \\
\text { Level }\end{array}$ \\
\hline 1.Apoya & 78.86 & I & 75.29 & I & 84.57 & $\mathrm{I}$ & 84.29 & I & 79.86 & I \\
\hline 2.Barles & 64.00 & $\mathrm{~F}$ & 76.27 & I & 83.45 & I & 79.71 & I & 73.43 & $\mathrm{~F}$ \\
\hline 3.Bilog & 76.67 & I & 80.57 & I & 85.71 & I & 85.71 & I & 80.00 & I \\
\hline 4.Espinosa & 91.00 & $\mathrm{~N}$ & 89.90 & $\mathrm{~N}$ & 86.71 & I & 85.18 & I & 92.68 & $\mathrm{~N}$ \\
\hline 5.Gidoc & 70.29 & $\mathrm{~F}$ & 59.14 & $\mathrm{~F}$ & 76.86 & I & 79.71 & I & 78.40 & I \\
\hline 6.Hernandez & 75.00 & I & 78.00 & I & 77.14 & I & 53.16 & $\mathrm{~F}$ & 75.68 & I \\
\hline 7.Landicho & 76.29 & I & 82.00 & I & 75.43 & I & 78.60 & I & 61.71 & $\mathrm{~F}$ \\
\hline 8.Las & 79.14 & I & 54.00 & $\mathrm{~F}$ & 73.14 & $\mathrm{~F}$ & 78.51 & I & 81.71 & I \\
\hline 9.Leyrit & 56.29 & $\mathrm{~F}$ & 62.00 & $\mathrm{~F}$ & 75.45 & I & 56.00 & $\mathrm{~F}$ & 61.71 & $\mathrm{~F}$ \\
\hline 10.Llanes & 78.00 & I & 75.71 & I & 77.14 & I & 76.04 & I & 79.43 & I \\
\hline 11.Marasigan & 79.43 & I & 79.86 & I & 75.13 & I & 79.43 & I & 68.57 & $\mathrm{~F}$ \\
\hline 12.Mendoza & 84.86 & I & 89.43 & I & 77.71 & I & 62.00 & $\mathrm{~F}$ & 63.71 & $\mathrm{~F}$ \\
\hline 13.Mercado & 71.14 & $\mathrm{~F}$ & 64.86 & $\mathrm{~F}$ & 77.71 & I & 78.29 & I & 55.43 & $\mathrm{~F}$ \\
\hline 14.Mosca & 76.00 & I & 76.57 & I & 66.57 & $\mathrm{~F}$ & 59.14 & $\mathrm{~F}$ & 53.71 & $\mathrm{~F}$ \\
\hline 15.Orola & 85.71 & I & 87.14 & I & 88.57 & I & 88.57 & I & 82.57 & I \\
\hline 16.Palomino, A & 63.71 & $\mathrm{~F}$ & 77.43 & I & 70.57 & $\mathrm{~F}$ & 58.86 & $\mathrm{~F}$ & 66.29 & $\mathrm{~F}$ \\
\hline 17.Palomino, $\mathrm{Z}$ & 64.00 & $\mathrm{~F}$ & 86.57 & I & 82.86 & I & 50.86 & $\mathrm{~F}$ & 83.71 & I \\
\hline 18.Salon & 82.57 & I & 60.29 & $\mathrm{~F}$ & 61.14 & $\mathrm{~F}$ & 56.87 & $\mathrm{~F}$ & 62.00 & $\mathrm{~F}$ \\
\hline 19.Umali & 76.29 & I & 76.57 & I & 63.43 & $\mathrm{~F}$ & 78.29 & I & 51.43 & $\mathrm{~F}$ \\
\hline 20.Abanilla & 81.14 & I & 88.57 & I & 85.14 & I & 60.29 & $\mathrm{~F}$ & 89.71 & I \\
\hline 21.Balat & 78.29 & I & 90.00 & $\mathrm{~N}$ & 90.29 & $\mathrm{~N}$ & 85.14 & I & 78.14 & I \\
\hline 22.Dalangin & 80.29 & I & 86.00 & I & 88.86 & I & 85.71 & I & 94.00 & $\mathrm{~N}$ \\
\hline 23.Gadingan & 93.97 & $\mathrm{~N}$ & 91.76 & $\mathrm{~N}$ & 95.90 & $\mathrm{~N}$ & 92.13 & $\mathrm{~N}$ & 92.76 & $\mathrm{~N}$ \\
\hline 24.Landicho & 77.14 & I & 82.86 & I & 84.57 & I & 82.57 & I & 94.86 & $\mathrm{~N}$ \\
\hline 25.Las & 60.57 & $\mathrm{~F}$ & 80.57 & I & 86.57 & I & 80.86 & I & 82.00 & I \\
\hline 26.Leyesa & 38.57 & $\mathrm{~F}$ & 30.57 & $\mathrm{~F}$ & 38.00 & $\mathrm{~F}$ & 45.71 & $\mathrm{~F}$ & 49.14 & $\mathrm{~F}$ \\
\hline 27.Llanes & 44.29 & $\mathrm{~F}$ & 38.29 & $\mathrm{~F}$ & 50.29 & $\mathrm{~F}$ & 51.43 & $\mathrm{~F}$ & 49.71 & $\mathrm{~F}$ \\
\hline 28.Mendoza & 80.86 & I & 85.71 & I & 80.86 & I & 80.57 & I & 81.14 & I \\
\hline 29.Moster & 82.00 & I & 88.00 & I & 62.29 & $\mathrm{~F}$ & 89.43 & I & 61.43 & $\mathrm{~F}$ \\
\hline 30.Navarro & 88.29 & I & 50.57 & $\mathrm{~F}$ & 53.71 & $\mathrm{~F}$ & 48.86 & $\mathrm{~F}$ & 44.86 & $\mathrm{~F}$ \\
\hline 31.Pader & 95.68 & $\mathrm{~N}$ & 90.34 & $\mathrm{~N}$ & 90.87 & $\mathrm{~N}$ & 92.94 & $\mathrm{~N}$ & 92.76 & $\mathrm{~N}$ \\
\hline 32.Palomino, $\mathrm{K}$ & 94.67 & $\mathrm{~N}$ & 92.19 & $\mathrm{~N}$ & 93.45 & $\mathrm{~N}$ & 91.89 & $\mathrm{~N}$ & 95.13 & $\mathrm{~N}$ \\
\hline 33.Pasahol, E & 87.14 & I & 87.43 & $\mathrm{I}$ & 78.86 & I & 78.59 & I & 83.71 & I \\
\hline 34.Pasahol, L & 80.29 & I & 80.29 & I & 80.86 & I & 78.00 & I & 81.43 & I \\
\hline 35.Claveria & 82.98 & I & 80.37 & I & 83.26 & I & 79.55 & I & 80.13 & I \\
\hline 36.Millave & 89.43 & I & 75.71 & I & 93.71 & I & 89.14 & I & 78.57 & I \\
\hline 37.April & 77.23 & I & 80.37 & I & 81.17 & I & 79.84 & I & 79.34 & I \\
\hline
\end{tabular}

Note. I: Instructional, F: Frustration, N: Independent, Com: Comprehension.

Table 2 reveals the results of the comprehension level of pupils in each reading sub-skills. The readings given revealed the pupils comprehension on the five English skills considered in the study. These skills were noting details, getting the main idea, predicting outcome, sequencing of events and giving cause and effect. These five sub-skills contained in the ABRC Module were considered in improving the reading comprehension of Grade V pupils.

The findings revealed in Table 2 that the comprehension level obtained in noting details were 4 or $11 \%$ independent, 24 or $65 \%$ instructional and 9 or $24 \%$ frustration. Comprehension level in getting the main idea obtained scores of 5 or $14 \%$ independent, 25 or $68 \%$ instructional and 7 or $19 \%$ frustration of the total score. In sub-skills, predicting outcome, 5 children or $14 \%$ got a comprehension level of independent, 23 or $62 \%$ belongs to instructional and 9 or $24 \%$ frustration. Sequencing events in the story obtained a comprehension level of 3 or $8 \%$ independent, 24 or $65 \%$ instructional and 10 or $27 \%$ frustration. The last skills which are cause and effect got 6 or $16 \%$ independent, 17 or $46 \%$ instructional and 14 or $38 \%$ frustration. 
De Belen, A. M.

Table 3

Comprehension level of grade v pupils using PHIL-IRI post-test

\begin{tabular}{|c|c|c|c|}
\hline Name of pupils & Independent & Instructional & Frustration \\
\hline 1. Apoya & $\mathrm{X}$ & & \\
\hline Barles & & & $X$ \\
\hline 3. Bilog & & $\mathrm{X}$ & \\
\hline 4. Espinosa & $\mathrm{X}$ & & \\
\hline 5. Gidoc & & & $\mathrm{X}$ \\
\hline 6. Hernandez & & $\mathrm{X}$ & \\
\hline Landicho & $\mathrm{X}$ & & \\
\hline 8. Las & $\mathrm{X}$ & & \\
\hline 9. Leyrit & & & $\mathrm{X}$ \\
\hline 10. Llanes & & $\mathrm{X}$ & \\
\hline 11. Marasigan & & $\mathrm{X}$ & \\
\hline 12. Mendoza & & $\mathrm{X}$ & \\
\hline 13. Mercado & & $\mathrm{X}$ & \\
\hline 14. Mosca & & $\mathrm{X}$ & \\
\hline 15. Orola & $\mathrm{X}$ & & \\
\hline 16. Palomino, A & & $\mathrm{X}$ & \\
\hline 17. Palomino, $\mathrm{Z}$ & $\mathrm{X}$ & & \\
\hline 18. Salon & $\mathrm{X}$ & & \\
\hline 19. Umali & & & $\mathrm{X}$ \\
\hline 20. Abanilla & $\mathrm{X}$ & & \\
\hline 21. Balat & $\mathrm{X}$ & & \\
\hline 22. Dalangin & $\mathrm{X}$ & & \\
\hline 23. Gadingan & $\mathrm{X}$ & & \\
\hline 24. Landicho & $\mathrm{X}$ & & \\
\hline 25. Las & & $\mathrm{X}$ & \\
\hline 26. Leyesa & & & $\mathrm{X}$ \\
\hline 27. Llanes & & & $X$ \\
\hline 28. Mendoza & $\mathrm{X}$ & & \\
\hline 29. Moster & $\mathrm{X}$ & & \\
\hline 30. Navarro & & $\mathrm{X}$ & \\
\hline 31. Pader & $\mathrm{X}$ & & \\
\hline 32. Palomino, $\mathrm{K}$ & $\mathrm{X}$ & & \\
\hline 33. Pasahol, E & $\mathrm{X}$ & & \\
\hline 34. Pasahol, L & & $\mathrm{X}$ & \\
\hline 35. Claveria & $\mathrm{X}$ & & \\
\hline 36. Millave & $\mathrm{X}$ & & \\
\hline 37. April & & $\mathrm{X}$ & \\
\hline
\end{tabular}

Table 3 shows the comprehension level of Grade V pupils using PHIL-IRI Test. This reveals that using ABRC module the comprehension level of Grade $\mathrm{V}$ pupils improved in the Post-test compared to Pretest of the PHIL-IRI before. Independent group obtained a score of 19 or 52\%. Instructional got 12 or 32\%. Frustration got the lowest score of 6 or $16 \%$.

Table 4 presents the difference of Pre and Post Comprehension Level of Grade V pupils. The results revealed that $100 \%$ of the pupils increased their level comprehension. It was noted that almost half in the independent level which marked the study impressive. Though, there was still $16 \%$ of the class still fell under the frustration level, the teacher will continue giving intervention to these pupils during summer. They will be given reading materials to read by the pupil. While, Table 5 presents the Plan of Action addressed to the pupils' needs based on the findings met. Based on the results of the study, the use of modules in attaining high comprehension level in English $\mathrm{V}$ is very effective. The researcher encouraged to continue using other reading modules to improve their pupils' performance. 
Effects of ABRC module utilization in improving reading comprehension of pupils in Tangway Loob school

Table 4

Difference of pre and post comprehension level of pupils

\begin{tabular}{|c|c|c|c|c|c|c|}
\hline \multirow{2}{*}{\multicolumn{2}{|c|}{ Name of pupils }} & \multicolumn{2}{|c|}{ Pre - Test } & \multicolumn{2}{|c|}{ Post - Test } & \multirow{3}{*}{$\begin{array}{c}\text { Increase/Decrease In } \% \\
\text { Increased }\end{array}$} \\
\hline & & \multirow{2}{*}{$\begin{array}{l}\% \\
62.50\end{array}$} & \multirow{2}{*}{$\begin{array}{l}\text { Description } \\
\text { Frustration }\end{array}$} & \multirow{2}{*}{$\begin{array}{l}\% \\
100.00\end{array}$} & \multirow{2}{*}{$\begin{array}{l}\text { Description } \\
\text { Independent }\end{array}$} & \\
\hline 1. & Apoya & & & & & \\
\hline 2. & Barles & 50.00 & Frustration & 62.50 & Frustration & Increased \\
\hline 3. & Bilog & 37.50 & Frustration & 75.00 & Instructional & Increased \\
\hline 4. & Espinosa & 92.00 & Independent & 100,00 & Independent & Increased \\
\hline 5. & Gidoc & 37.50 & Frustration & 62.50 & Frustration & Increased \\
\hline 6. & Hernandez & 50.00 & Frustration & 75.00 & Instructional & Increased \\
\hline 7. & Landicho & 25.00 & Frustration & 92.50 & Independent & Increased \\
\hline 8. & Las & 37.50 & Frustration & 91.15 & Independent & Increased \\
\hline 9. & Leyrit & 37.50 & Frustration & 62.50 & Frustration & Increased \\
\hline 10. & Llanes & 25.00 & Frustration & 50.00 & Instructional & Increased \\
\hline 11. & Marasigan & 50.00 & Frustration & 75.00 & Instructional & Increased \\
\hline 12. & Mendoza & 62.50 & Frustration & 87.50 & Instructional & Increased \\
\hline 13. & Mercado & 37.50 & Frustration & 75.00 & Instructional & Increased \\
\hline 14. & Mosca & 50.00 & Frustration & 75.00 & Instructional & Increased \\
\hline 15. & Orola & 87.50 & Instructional & 90.00 & Independent & Increased \\
\hline 16. & Palomino, A & 50.00 & Frustration & 87.50 & Instructional & Increased \\
\hline 17. & Palomino, Z & 50.00 & Frustration & 75.00 & Instructional & Increased \\
\hline 18. & Salon & 75.00 & Instructional & 92.00 & Independent & Increased \\
\hline 19. & Umali & 37.50 & Frustration & 62.50 & Frustration & Increased \\
\hline 20. & Abanilla & 75.00 & Instructional & 100.00 & Independent & Increased \\
\hline 21. & Balat & 87.50 & Instructional & 100.00 & Independent & Increased \\
\hline 22. & Dalangin & 87.50 & Instructional & 100.00 & Independent & Increased \\
\hline 23. & Gadingan & 92.15 & Independent & 100.00 & Independent & Increased \\
\hline 24. & Landicho & 62.50 & Frustration & 92.00 & Independent & Increased \\
\hline 25. & Las & 50.00 & Frustration & 87.50 & Instructional & Increased \\
\hline 26. & Leyesa & 50.00 & Frustration & 62.50 & Frustration & Increased \\
\hline 27. & Llanes & 37.50 & Frustration & 50.00 & Frustration & Increased \\
\hline 28. & Mendoza & 62.50 & Frustration & 91.52 & Independent & Increased \\
\hline 29. & Moster & 62.50 & Frustration & 92.00 & Independent & Increased \\
\hline 30. & Navarro & 62.50 & Frustration & 87.50 & Instructional & Increased \\
\hline 31. & Pader & 92.71 & Independent & 100.00 & Independent & Increased \\
\hline 32. & Palomino, $\mathrm{K}$ & 91.67 & Independent & 100.00 & Independent & Increased \\
\hline 33. & Pasahol, E & 87.50 & Instructional & 100.00 & Independent & Increased \\
\hline 34. & Pasahol, L & 62.50 & Frustration & 87.50 & Instructional & Increased \\
\hline 35. & Claveria & 62.50 & Frustration & 100.00 & Independent & Increased \\
\hline 36. & Millave & 87.50 & Instructional & 100.00 & Independent & Increased \\
\hline 37. & April & 62.50 & Frustration & 87.50 & Instructional & Increased \\
\hline
\end{tabular}

Table 5

Plan of action: Using of ABRC module in English $V$

\begin{tabular}{|c|c|c|c|c|c|c|}
\hline Program & Objectives & Activities/strategies & Personnel involved & $\begin{array}{c}\text { Target } \\
\text { clientele }\end{array}$ & $\begin{array}{l}\text { Time } \\
\text { frame }\end{array}$ & Success indicator \\
\hline \multirow{3}{*}{$\begin{array}{l}\text { Using of } \\
\text { ABRC } \\
\text { Module in } \\
\text { English } 5\end{array}$} & $\begin{array}{l}\text { I. Pupils } \\
\text { 1. Raise the quality of } \\
\text { performance of pupils } \\
\text { in English V } \\
\text { 2. Improve some more } \\
\text { skills in English V }\end{array}$ & $\begin{array}{l}\text { Use of ABRC Module in } \\
\text { remedial classes which } \\
\text { could be individual, } \\
\text { pairing or in groups }\end{array}$ & $\begin{array}{l}\text { Teacher } \\
\text { School Head }\end{array}$ & $\begin{array}{l}\text { Grade } 5 \\
\text { and } 6 \\
\text { pupils } \\
\text { Slow } \\
\text { learner in } \\
\text { Grade } 5\end{array}$ & $\begin{array}{l}\text { June to } \\
\text { March } \\
1^{\text {st }} \text { to } \\
4^{\text {th }} \\
\text { quarter }\end{array}$ & $\begin{array}{l}\text { With at least } 75 \% \\
\text { mastery level of } \\
\text { performance of pupils } \\
\text { With at least } 75 \% \\
\text { mastery level of } \\
\text { performance of slow } \\
\text { learners }\end{array}$ \\
\hline & $\begin{array}{l}\text { II. Teachers } \\
\text { Use of ABRC } \\
\text { Module in English }\end{array}$ & $\begin{array}{l}\text { Prioritize the use of } \\
\text { modules }\end{array}$ & $\begin{array}{l}\text { Teachers } \\
\text { School Head }\end{array}$ & Teachers & $\begin{array}{l}\text { June to } \\
\text { March }\end{array}$ & $\begin{array}{l}100 \% \text { of the teachers } \\
\text { use ABRC Modules } \\
\text { suited for the learners }\end{array}$ \\
\hline & $\begin{array}{l}\text { Develop a Module in } \\
\text { developing skills of } \\
\text { pupils in English }\end{array}$ & $\begin{array}{l}\text { Use modules in } \\
\text { developing the skills in } \\
\text { English V and VI }\end{array}$ & $\begin{array}{l}\text { Teachers } \\
\text { School Head }\end{array}$ & Teachers & $\begin{array}{l}\text { Year } \\
\text { Round }\end{array}$ & $\begin{array}{l}100 \% \text { of the teachers } \\
\text { develop a module } \\
\text { which can provide } \\
\text { varied and challenging } \\
\text { activities to develop } \\
\text { pupils' skills in } \\
\text { English V and VI }\end{array}$ \\
\hline
\end{tabular}




\section{Conclusion}

From the summarized findings, the following conclusions were drawn:

Based on the study, the comprehension level of Grade V pupils in Tangway Loob Elementary School before the utilization of the ABRC Module is very low. Many children fall in frustration level which got a percentage of $70 \%$.

D The pupil's comprehension level in noting details is 76.40, getting main idea, 76.52, predicting outcome, 77.78 , sequencing events in the story 74.65 and giving cause and effect 74.62 . The comprehension level of pupils in the five subs kills fall in the instructional level.

D The comprehension level of Grade V pupils after the use of ABRC module increased in the PHIL -IRI Posttest compared to its Pretest. Independent level before the utilization of ABRC module is $11 \%$ and it increased to $32 \%$. Instructional level is $19 \%$ and it rose to $32 \%$. Frustration level got a score of $70 \%$ and it decreased to $16 \%$.

$>$ There is a significance difference in the comprehension of the pupils before and after the utilization of the ABRC module. The independent level of pupils raised to $21 \%$, instructional level $13 \%$ and frustration level decreased to $54 \%$.

\subsection{Recommendations}

From the drawn conclusions, the following recommendations are hereby forwarded:

D A school-based seminar workshop on modules integrated with research should be conducted to improve the teachers' instructional and research skills and competencies.

$>$ The future researchers may conduct similar studies or those related to the present study to determine and strengthen even more the findings of this present study.

$>$ The researchers recommend that teachers teaching English V should make use of the ABRC module, and other schools may adopt the said module.

\section{References}

Armbuster, B. B., Lehr, F., \& Osborn, J. (2001). Put reading first: The research building blocks for teaching children to read. Jesup, MD: National Institute for Literacy.

Keene, E. K., \& Zimmerman, S. (1997). Mosaic of thought: Teaching comprehension in a reading workshop. Portsmouth, NH: Heinemann.

Palinscar, A. S., \& Brown, A. L. (1985). Reciprocal teaching: Activities to promote "reading with your mind." In E. J. Cooper (Ed.), Reading, thinking and concept development: Interactive strategies for the class (pp. 147-159). New York, NY: College Board. 